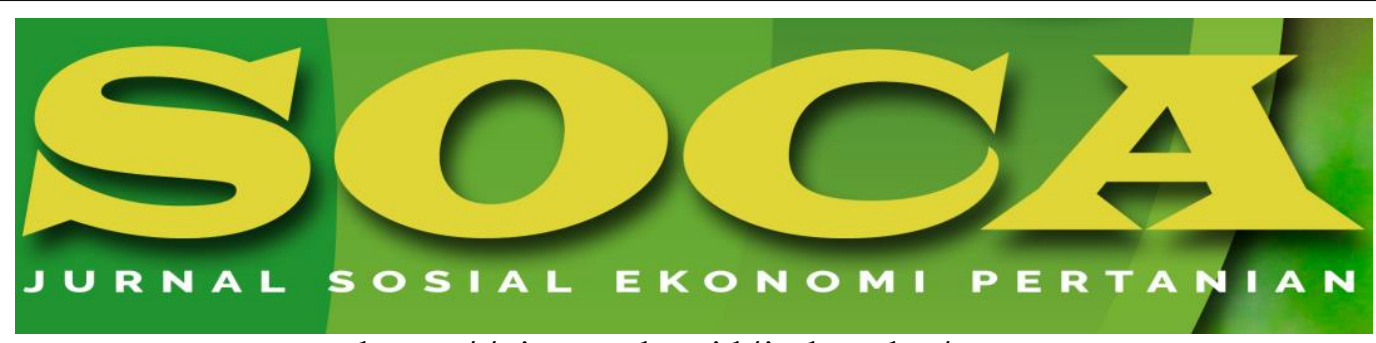

https://ojs.unud.ac.id/index.php/soca

\title{
The Development of Rice Field Area in Special Region of Yogyakarta
}

\author{
Abi Pratiwa Siregar ${ }^{1}$,Nadia Oktaviana ${ }^{2}$ and Edy Rahmantyo Tarsilohadi ${ }^{3}$ \\ 1,2Faculty of Agriculture, Gadjah Mada University, Special Region of Yogyakarta \\ ${ }^{3}$ Faculty of Economics and Business, Bengkulu University \\ Correspondence email: abipratiwasiregar@ugm.ac.id \\ Mobile: 082136014995
}

Submitted: April 7th 2020; Revised: April 13th, 2020; Accepted: May 3rd, 2020

\begin{tabular}{|c|c|}
\hline & Abstract \\
\hline $\begin{array}{l}\text { Keywords: } \\
\text { Special Region } \\
\text { of Yogyakarta; } \\
\text { Land } \\
\text { conversion; } \\
\text { Forecasting } \\
\text { Model; Linear } \\
\text { trend; Non- } \\
\text { linear trend }\end{array}$ & $\begin{array}{l}\text { In general, the development of agricultural land usage change } \\
\text { was illustrated through linear trend analysis without } \\
\text { comparing it first with other trend analysis. As a consequence, } \\
\text { it was assumed that the data will be in a straight line with a } \\
\text { tendency for constant numbers over a period of time. However, } \\
\text { the facts on the ground proved that the area of agricultural land } \\
\text { converted into non-agricultural land was not always the same } \\
\text { from year to year. The novelty of this research was to do a } \\
\text { comparison between linear and non-linear trends to predict the } \\
\text { development of rice fields, so that an accurate forecasting } \\
\text { model was obtained. The aim of this research were: } 1 \text { ) knowing } \\
\text { the development of rice fields area in the Special Region of } \\
\text { Yogyakarta, 2) determining the appropriate forecasting model } \\
\text { for the development of rice fields area in the Special Region of } \\
\text { Yogyakarta, and 3) forecasting the area of rice fields in the } \\
\text { Special Region of Yogyakarta. The data that used came from } \\
\text { BPS (Central Bureau of Statistics) from } 1996 \text { to } 2017 \text {. The } \\
\text { trend models being compared were linear trends, quadratic } \\
\text { trends, and exponential trends. The results showed that the } \\
\text { area of rice fields in the Special Region of Yogyakarta tended to } \\
\text { decrease from year to year. The best forecasting model was an } \\
\text { exponential trend. In } 2017 \text { to } 2021 \text {, it was estimated that there } \\
\text { will be a decrease in rice field area of } 221 \text { hectares or } 0.41 \\
\text { percent per year. }\end{array}$ \\
\hline
\end{tabular}


How to Cite (APA 6th Style):

Siregar, A. P.,Oktaviana N., Tarsilohadi E. R. (2020). The Development of Rice Field Area in Special Region of Yogyakarta. SOCA: Jurnal Sosial Ekonomi Pertanian, 14(3), 558-572.

https://doi.org/https://doi.org/10.24843/SOCA.2020.v14.i03.p16

\section{INTRODUCTION}

Technology in the agricultural sector which was growing even now in the stage of digitalization, still cannot replace the strategic role of land as a production factor. Among the various types of land available, rice fields played an important role as a major producer of food, which was paddy that will then be processed into rice. (Adimihardja, 2006; Isa, 2006; Catur et al., 2010; Ritung, 2010; Maulana \& Ma'rif, 2019; BPS, 2020). For this crucial role, the availability of rice field area data was important, because it can provide an overview of the amount of food available or can be linked to food security in an area (Irawan \& Ariningsih, 2010).

An area was said to be able or not to meet the rice needs of its population if the amount of production was greater than the need for rice (the population multiplied by consumption per capita). Conversely, if the need for rice was greater than the production that produced in the region, then the main choice was to bring rice from other regions. The greater the deficit in the rice balance, the greater the dependence on the exporter region. The impact, if the exporters experienced a production disruption, there will be turmoil in the region of rice importers, which was generally indicated by an increase in prices which resulted in a decrease in consumer purchasing power (Zulfikar et al., 2013; Abdillah \& Zaini, 2018).

From 2003 to 2015, Indonesia created 210,828 hectares of new rice fields (BPS, 2020b). However, the trend in the last three years (2013 to 2015) was that land conversion was greater than the creation of new land. It was recorded a decrease in the area of rice fields by 41,106 hectares. In general, agricultural land that was converted into settlements and/or commercial areas (Widjanarko et al., 2001; Dewi $\&$ Rudiarto, 2013). The consequence of productive land conversion was that it can cause problems in the environmental, economic and social aspects, as well as the potential of the land itself (Irawan, 2005; Irawan in Jawawi et al., 2016).

Ashari (2003) expressed that land conversion had occurred a long time ago and was a difficult thing to avoid in the midst of massive development. Among the regions in Indonesia, Java Island was the area with the largest land conversion, including the Special Region of Yogyakarta. Although listed as the second smallest province in Indonesia, the Special Region of Yogyakarta was inseparable from the reduction of agricultural land to non-agricultural land (Hidayatullah \& Perihatini, 2016). Irawan \& Friyatno (2002) informed that from the Pelita III to Pelita VI periods (1981 - 1998), the rate of land conversion was 823 hectares per year.

Special Region of Yogyakarta has special status or special autonomy. Before Indonesia independence, in this region the royal law had been applied, where there were rules regarding land matters. Regarding this matter, the Government through the 1945 Constitution (UUD 1945) clause 18 provided recognition of the status of privileges owned by certain regions before the establishment of the republic. Therefore, although nationally it was governed by land governance, DIY can manage its own land based on rules and regulations that had already been applied. This was 
then considered as the matter of making lands in DIY became faltering between national land, resident land, Sultan's land (Sultan Ground), and Pakualaman land (Pakualaman Ground). In fact, in 2012, Law No. 13 of 2012 concerning in Regional Privileges was issued, in which one of the points was the strengthening of DIY's legitimacy in managing land (Jati, 2014; Dwiyansany et. Al., 2019).

On the basic of strong and sustainable cultural values, local wisdom, natural beauty, and was one of the centers of education, Special Region of Yogyakarta was visited by tourists in relatively large numbers from year to year. These tourists not only came from domestic but also foreign tourists. Among these tourists, some even decided to stay and settle in this region (Telaumbanua \& Pitoyo, 2017). This had a direct impact on the increasing land requirements for settlements and commercial areas. Among the available land, one of the most common functions was rice fields. Even so, the sale and purchase of land in the Special Region of Yogyakarta can only be done on land that has been certified ownership or private ownership land. On land with the status of Sultan's land or Pakualaman land, the community only had usage rights, so there was no legality to transfer ownership.

The need for food was a basic thing for humans. Therefore, with the information on the availability of rice fields, it will be known how far an area was able to meet the food needs of its population, in this case rice. However, over time, the economy of a region also moved dynamically, so it was necessary to estimate the ability of the region in the future. To be able to estimate well, we need the right forecasting model.

Prasada \& Rosa (2018) used BPS data to determine the area and the conversion rate of rice fields in the Special Region of Yogyakarta from 2006 to 2015. Based on the research results, it was known that the shrinkage rate in rice fields was 0.48 percent per year. Using BPS data, Nurelawati et al. (2018) conducted a research of trends in the conversion of rice fields in Klaten Regency. The results of her research concluded that each year the area of rice fields decreased by 38 hectares or if presented at 0.12 per year. On the other hand, Wibowo (2015) obtained data on rice fields area from the Agricultural and Fisheries Counseling Agency in Jaten SubDistrict, Karanganyar Regency. Based on the results of the processed data, it was known that every year from 2014 to 2018, rice fields in Jaten Sub-District were reduced by around 20 hectares.

In general, after knowing the conversion rate of agricultural land, a trend analysis of the conversion rate was performed. As found in the research of Hidayat (2008), Putri (2015), Faisaluddin et al. (2019), and Yoga Prasada \& Masyhuri (2020).

Hidayat (2008) used linear trend analysis with the least squares method to determine the development of rice field area used in East Java which had a decrease tendency, while the development of land area used for yards/buildings in the last 10 years had increased. Based on the results of the research, it was known that the trend of land area for rice fields had a decrease trend with a multiplier value of 2,264.9. That was, in the following year in East Java, there will be a decrease in the area of rice fields around $-2,264.9$ hectares.

Putri (2015) used time series data to project the conversion of agricultural land to non-agricultural land in the next few years by using the trend analysis forecasting model. The dependent variable was land conversion, while the independent variable was time. The analysis showed that the development of land 
conversion and rice production in Central Java Province continued to increase continuously every year.

Faisaluddin et al. (2019) used simple linear regression to predict availability of rice fields. Based on the results of trend analysis, the equation $\hat{\mathrm{Y}}=2,440-99,80 \mathrm{x}$ was obtained. That means, it was estimated that every year there will be a change in the area of rice fields around 90 hectares.

Yoga Prasada \& Masyhuri (2020) used trend analysis to determine the availability of agricultural land. Trend analysis was used to find out whether there was an increasing tendency or vice versa, decrease tendency in the area of agricultural land. Through trend analysis, the equation $\mathrm{Y}=1,830.5-25.56 \mathrm{X}$ was obtained. The coefficient that showed the negative sign indicated that there was a negative correlation between the area of rice fields and the independent variable (time). It means, in the future, every year there will be a decrease in the area of rice fields around 25.56 hectares per year.

Based on the results of the existing research, the whole was using trend analysis or more precisely the trend analysis of the least squares method (linear). In linear trend analysis, it was assumed that a trend line was a straight line. But in reality, the area of rice fields had fluctuated, so it was not always a straight line.

To illustrate a data tendency, in addition to linear trend analysis, quadratic trend analysis and exponential trend analysis were also available. If a set of data, based on the scatter diagram showed a linear increase or decrease, then a linear trend was used. However, if the scatter diagram was in the form of a parabola both open up or open down, a quadratic trend was used. While exponential trends were used if the scatter diagram did not show a linear or quadratic model and after calculating the original logarithm of the data and apparently showed a linear form, then the exponent trend was used (Rahmawati, 2015; Sukerti, 2015).

Besides looking at scatter diagrams, another way to find out the best forecasting model can be found in the research of Sukiyono \& Rosdiana (2018) and Sakinah et al. (2018) which used Mean Absolute Percentage Error (MAPE), Mean Absolute Deviation (MAD) and Mean Squared Deviation (MSD). MAPE is a comparison of the absolute number of errors with the number of periods of a forecast. MAD is the average absolute error over a certain period without regard to the forecasting result whether is greater or smaller than the reality, and MSD or MSE (Margin Squared Error) is the sum of the squared biased in a certain period (Rakhman \& Puspitasari, 2017).

The novelty of this research were: 1) presented information on the development of rice fields area in the Special Region of Yogyakarta in a relatively longer period than the previous literature, 2) determined the forecasting model to get the best forecasting model so that what was estimated can be as close as possible to reality, and 3) forecasting the area of rice fields based on the best forecasting model, not necessarily a linear trend model.

The aim of this research was to: 1) determine the development of rice fields area in the Special Region of Yogyakarta, 2) determine the appropriate forecasting model for the development of rice fields area in the Special Region of Yogyakarta, and 3) make forecasting of the rice fields area in the Special Region of Yogyakarta . The urgency of this research was to provide a need for a comprehensive picture of the current and future availability of rice fields in the Special Region of Yogyakarta. Because by knowing 
these conditions, control or planning efforts can be made so that population needs of rice can be fulfilled in a sustainable manner.

\section{RESEARCH METHODS}

This research used descriptive analytical method which was a method that provided a picture of the actual situation of the object under study based on the facts that existed by collecting, processing, and analyzing various kinds of data so that a conclusion can be drawn (Rori, 2013). The type of data in this research was secondary data from the Central Bureau of Statistics from 1996 to 2017. The time range of the data adjusted to the availability of data based on the publications published by the Central Bureau of Statistics.

The area that became the object of research was the Special Region of Yogyakarta with the consideration that this region was the second smallest province in Indonesia, but had a tourism sector that continued to grow massively, and was also predicate as an educational center. An increase in population, growth in the number of tourist visits, and the increasing number of students studying in this region will be positively correlated to an increase in food needs, especially rice. Therefore, information was needed to know how far the rate of rice fields conversion and how the availability of rice fields in the future.

The first aim was known by using descriptive analysis and displayed with pictures. The second aim was known by comparing linear trend, quadratic trend, and exponential trend using MAD, MSD, and MAPE with the formula below. The best forecasting model was shown through the smallest value. For the third aim, it was known to use the forecasting model of the comparison results of MAD, MSD, and MAPE.

a. Linear Trend

$\mathrm{Y}=\mathrm{a}+\mathrm{bX}$

b. Quadratic Trend

$\mathrm{Y}=\mathrm{a}+\mathrm{bX}+\mathrm{cX}^{2}$

c. Exponential Trend

$\mathrm{Y}=\mathrm{a}(1+\mathrm{b})^{\mathrm{X}}$

d. MAD

$\mathrm{MAD}=\left(\sum(\mathrm{Yt}-\hat{\mathrm{Y} t})\right) / \mathrm{n}$

e. MSD

$\mathrm{MSD}=\sum\left((\mathrm{Yt}-\hat{\mathrm{Y}} \mathrm{t})^{2} / \mathrm{Yt}\right) / \mathrm{n}$

f. MAPE

$\mathrm{MAPE}=\left(\sum((\mathrm{Yt}-\hat{\mathrm{Y}} \mathrm{t}) / \mathrm{Yt}) / \mathrm{n}\right) \times 100 \%$

MAD (Mean Absolute Deviation) provided information about forecast deviations in the same unit in the data, by averaging the absolute value of the deviation from all forecasting results. Absolute value was useful to avoid the value of positive deviation and negative deviation canceled each other out. Another parameter, MSD (Mean Squared Deviation) was a measurement of forecast deviation by averaging the error quadrat (the deviation of all forecasts). Meanwhile, MAPE (Mean Absolute Percentage Error) or average absolute error percentage provided information on how much forecast error compared to the actual value (Sungkawa and Megasari, 2011; Robial, 2018). To determine and establish a good forecasting 
model, the smallest MAD, MSD, and MAPE numbers were chosen. That was because the smaller numbers indicated a better level of precision.

\section{RESULTS AND DISCUSSION}

\section{The development of rice fields area in the Special Region of Yogyakarta}

Special Region of Yogyakarta with all available resources had succeeded in attracting domestic and foreign tourists. In 2018, the Department of Tourism DIY (2019) recorded that there were a total of 5,688,091 tourist arrivals consisting of $5,272,719$ domestic tourists and 416,372 foreign tourists. That number grew $8.7 \%$ or as many as 459,793 people compared to the total tourist arrivals in 2017.

Besides the number of tourists increased from time to time, the average length of stay of tourists in star and non-star hotels in Special Region of Yogyakarta also increased from 2017 to 2018 by 0.02 points for foreign tourists to 2.13 days, and 0.01 points for domestic tourists to 1.98 days. The combination of the number of visits with a positive duration of stay encouraged investors to allocate their resources to establish star and other non-star hotels or other commercial buildings.

Special Region of Yogyakarta also got the nickname as the center of education. With an area of 3,186 km2, BPS (2019) noted that in the 2018/2019 school year, there were 11 universities with a total of 127,183 students. Meanwhile, in 2017, there were 103 private colleges with 227,409 students. This relatively large number of students had consequences in housing needs. So far, not all universities provided dormitories, so the providers of residential needs were the DIY society itself and investors by building boarding / rented houses.

From 1996 to 2016, the Special Region of Yogyakarta never established new rice fields. Conversely, the area of land was reduced by 7,968 hectares in a period of twenty years or around 257.5 hectares each year. To anticipate the dynamic rate of land conversion, the government then issued Law Number 41 of 2009 concerning Protection of Sustainable Food Agricultural Land and the DIY Government issued Local Regulation Number 10 of 2011 concerning Protection of Sustainable Agricultural Food Land. The regulation regulated the area of productive land that must be maintained as a Sustainable Food Agricultural Land, which an area of 35,911 hectares. However, in practice this policy still encountered various obstacles, which were 1) regional spatial planning policies that had not adequately protected existing land (food agricultural land), 2) violations of regional spatial planning regulations, 3) limited budget allocation for policy planning, 4) power holders and capital owners as an concerned group, 5) difficulty in obtaining farmers' willingness, and 6) limited availability of agricultural land (Janti et al., 2016). 


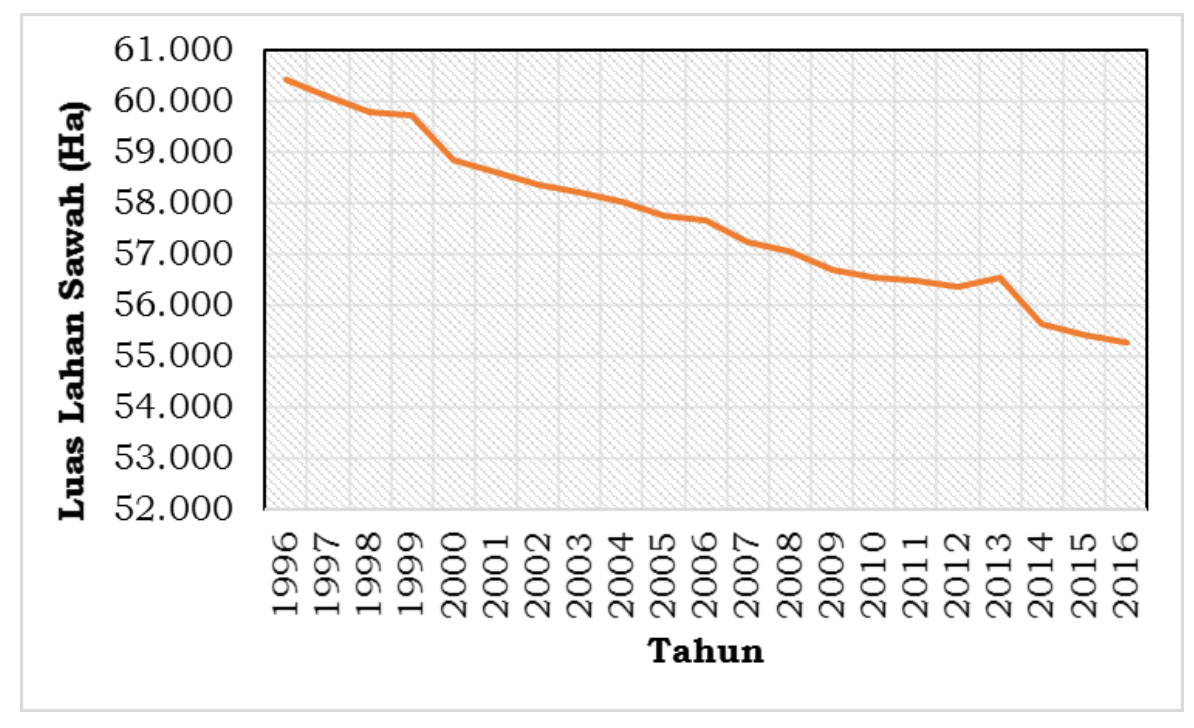

Picture 1. Rice Field Area in Special Region of Yogyakarta, 1996 - 2016 Source: Processed from BPS data

Picture information:

Luas lahan sawah $=$ rice field area $(\mathrm{Ha})$

Tahun $=$ year

\section{Appropriate forecasting model for the development of rice fields area in the Special Region of Yogyakarta}

In this research, it was assumed that the rice field area data from year to year moved dynamically. In accordance with the information in Table 1, the average land usage change was 257.5 hectares, but if it was reviewed annually, at a time, land conversion happened with multiplies area from the average value. To overcome this, a forecasting model with the smallest error was needed. Based on these considerations, linear trend analysis and non-linear trend analysis were used. The first time, a linear trend analysis was performed using the smallest quadrat. Through this method, it was assumed that the available data had a tendency to approach straight lines or linear equations.

Alfarisi \& Sunarmintyastuti (2018) said that the forecasting results were certainly not always the same as what was happening in real. The difference between forecast data and actual data was called forecast errors. The smaller the forecast error means the better a forecasting model.

Based on the results of the linear trend analysis, the equation $\hat{Y}=57.564 .52$ - 245.48X was obtained. By using these equations, a calculation was then performed to determine the forecast error value. A negative sign indicated that the forecasting result was lower than the real value. On the other hand, the positive sign reflected the forecast result which exceeded the real value. From 1996 to 2016, forecasting using the smallest quadrat method ever produced forecast errors of $0.0061 \%$ of the actual value. 
Table 1. Rice Field Area, Forecasting Result of Rice Field Area through Linear Trend Method (smallest quadrat), and error value (unit in hectare), 1996 - 2016

\begin{tabular}{cccc}
\hline Year & Rice Field Area & Forecasting Result of Rice Field Area & error \\
\hline 1996 & 60.442 & 60.119 & -323 \\
1997 & 60.110 & 59.874 & -236 \\
1998 & 59.792 & 59.628 & -164 \\
1999 & 59.742 & 59.383 & -359 \\
2000 & 58.858 & 59.137 & 279 \\
2001 & 58.608 & 58.892 & 284 \\
2002 & 58.367 & 58.646 & 279 \\
2003 & 58.210 & 58.401 & 191 \\
2004 & 58.050 & 58.155 & 105 \\
2005 & 57.762 & 57.910 & 148 \\
2006 & 57.661 & 57.665 & 4 \\
2007 & 57.261 & 57.419 & 158 \\
2008 & 57.081 & 57.174 & 93 \\
2009 & 56.712 & 56.928 & 216 \\
2010 & 56.538 & 56.683 & 145 \\
2011 & 56.491 & 56.437 & -54 \\
2012 & 56.364 & 56.192 & -172 \\
2013 & 56.539 & 55.946 & -593 \\
2014 & 55.650 & 55.701 & 51 \\
2015 & 55.425 & 55.455 & 30 \\
2016 & 55.292 & 55.210 & -82 \\
\hline
\end{tabular}

Source: Processed from BPS data, $1996-2017$

After the linear trend of the smallest quadrat method, the next was the quadratic trend. The assumption in this model was that the data available from year to year will form a parabolic line if a data distribution was made in the form of scatter diagrams. That was because in the short-term was the linear patterned data, but in the long-term it was not linear. Based on the calculation results, obtained the quadratic trend equation $\hat{Y}=57,517-245.48 X+1.983 X 2$. After a comparison, it was known that the forecast error was relatively large. In 2016, the forecast results were three times greater than the actual value.

Table 2. Rice Field Area, Forecasting Result of Rice Field Area through non-linear method (quadratic), and error value (unit in hectare), 1996 - 2016

\begin{tabular}{cccc}
\hline Year & Rice Field Area & $\begin{array}{c}\text { Forecasting Result of Rice } \\
\text { Field Area }\end{array}$ & error \\
\hline 1996 & 60.442 & 258.306 & 197.864 \\
1997 & 60.110 & 220.377 & 160.267 \\
1998 & 59.792 & 186.415 & 126.623 \\
1999 & 59.742 & 156.420 & 96.678 \\
2000 & 58.858 & 130.391 & 71.533 \\
2001 & 58.608 & 108.328 & 49.720 \\
2002 & 58.367 & 90.233 & 31.866
\end{tabular}




\begin{tabular}{cccc}
\hline Year & Rice Field Area & $\begin{array}{c}\text { Forecasting Result of Rice } \\
\text { Field Area }\end{array}$ & error \\
\hline 2003 & 58.210 & 76.104 & 17.894 \\
2004 & 58.050 & 65.942 & 7.892 \\
2005 & 57.762 & 59.746 & 1.984 \\
2006 & 57.661 & 57.518 & -143 \\
2007 & 57.261 & 59.255 & 1.994 \\
2008 & 57.081 & 64.960 & 7.879 \\
2009 & 56.712 & 74.631 & 17.919 \\
2010 & 56.538 & 88.269 & 31.731 \\
2011 & 56.491 & 105.874 & 49.383 \\
2012 & 56.364 & 127.445 & 71.081 \\
2013 & 56.539 & 152.983 & 96.444 \\
2014 & 55.650 & 182.487 & 126.837 \\
2015 & 55.425 & 215.959 & 160.534 \\
2016 & 55.292 & 253.397 & 198.105 \\
\hline
\end{tabular}

Source: Processed from BPS data, $1996-2017$

The final model was an exponential trend, assumed that the development of rice fields area from year to year was not the same. These assumptions were in accordance with the conversion rate of rice fields in the Special Region of Yogyakarta as shown in Picture 1. However, it was necessary to have an empirical study of whether the conversion rate of rice field area occurred exponentially or not. Through exponential trend analysis, the equation $\hat{Y}=57,644(1-0.0042) X$ was obtained.

The results of forecasting of rice fields area using exponential trends did not differ much from the results of linear trends. In certain years, there were the same forecasting error values, one of which occurred in 2006, with an error of 4 . Based on this, determined the correct forecasting model cannot be done through comparison of error values from year to year. In this research MAPE, MAD, and MSD were used.

Table 3. Rice Field Area, Forecasting Result of Rice Field Area through non-linear trend method (exponential), and error value (unit in hectare), 1996 - 2016

\begin{tabular}{cccc}
\hline Year & Rice Field Area & Forecasting Result of Rice Field Area & error \\
\hline 1996 & 60.442 & 60.119 & -323 \\
1997 & 60.110 & 59.874 & -236 \\
1998 & 59.792 & 59.628 & -164 \\
1999 & 59.742 & 59.383 & -359 \\
2000 & 58.858 & 59.137 & 279 \\
2001 & 58.608 & 58.892 & 284 \\
2002 & 58.367 & 58.646 & 279 \\
2003 & 58.210 & 58.401 & 191 \\
2004 & 58.050 & 58.155 & 105 \\
2005 & 57.762 & 57.910 & 148 \\
2006 & 57.661 & 57.665 & 4 \\
2007 & 57.261 & 57.419 & 158 \\
2008 & 57.081 & 57.174 & 93
\end{tabular}




\begin{tabular}{cccc}
\hline Year & Rice Field Area & Forecasting Result of Rice Field Area & error \\
\hline 2009 & 56.712 & 56.928 & 216 \\
2010 & 56.538 & 56.683 & 145 \\
2011 & 56.491 & 56.437 & -54 \\
2012 & 56.364 & 56.192 & -172 \\
2013 & 56.539 & 55.946 & -593 \\
2014 & 55.650 & 55.701 & 51 \\
2015 & 55.425 & 55.455 & 30 \\
2016 & 55.292 & 55.210 & -82 \\
\hline
\end{tabular}

Source: Processed from BPS data, 1996 - 2017

Justification of the best forecasting model was done by comparing the values of MAPE, MAD, and MSD. Among the three trend models, exponential trends and linear trends (smallest quadrat) had a very small difference in the value of MAPE. However, based on the MAD and MSD values, there were significant differences. Therefore, because an appropriate model was one that had the smallest forecasting error value, then the exponential trend was the best model for estimating the area of rice fields in the Special Region of Yogyakarta.

Table 4. Linear Trend Value (smallest quadrat), Quadratic Trend, and Exponential Trend based on MAPE, MAD, dan MSD

\begin{tabular}{ccccc}
\hline No & Parameter & Linear (smallest quadrat) & Quadratic & Exponential \\
\hline 1 & MAPE & 0,0027 & 1,0566 & 0,0026 \\
2 & MAD & 158,6341 & $60.974,8833$ & 151,2276 \\
3 & MSD & $44.694,9378$ & $7.939 .905 .448,8252$ & $41,180,6230$ \\
\hline
\end{tabular}

Source: Processed from BPS data

\section{The forecasting to rice fields area in the Special Region of Yogyakarta}

The most recent data on rice field area in the Special Region of Yogyakarta was in 2017. In the previous calculations, 2017 was not included. The reason was it used to determine whether the selected forecasting model was the most appropriate for predicting the rice fields area in the future, when compared with other models that were not selected.

MAPE comparison results showed that exponential trends and linear trends differ only slightly. Therefore, in predicting the rice fields area in the Special Region of Yogyakarta, exponential trend was used as the chosen forecasting model and linear trend as the closest comparison. The result, an exponential trend was indeed the most appropriate model. In 2017, through BPS publication, it was informed that in the Special Region of Yogyakarta there were 52,474 hectares of rice fields. The exponential forecasting result was only 25 hectares or around 0.048 percent, better than the linear trend of -210 hectares or $-0.04003 \%$.

It was estimated that the rice field area in the Special Region of Yogyakarta will continue to decrease from 2017 to 2021. The rate of land conversion was estimated to reach 221 hectares or 0.41 percent per year. The choice of an exponential forecasting model illustrated that the conversion of rice fields was categorized quickly with a number that tended to increase from year to year. This must be the focus of stakeholders regarding agricultural land and food availability. 
The policies that can be taken were categorized into two, which were direct and indirect. Policies that had a direct impact were monitoring the implementation of Sustainable Food Agricultural Land, tightening the rules on the rice field conversion to settlements and/or commercial areas, and promoting development vertically. On the other hand, policies that had an indirect impact were; trying to increase land productivity, farmers' accessibility to production facilities and markets, as well as support for the post-harvest process. This will play a role in the sustainability of farmers' farming, so farmers as landowners can maintain their rice fields.

The consequence that will be borne by the Special Region of Yogyakarta if it continued to let rice fields became non-agricultural land was the reduced availability of rice as a basic need of the community. On the other hand, the need for rice continued to increase, both to meet the needs of the community, tourists, and students from outside the area. Therefore, if at its peak there was then a rice balance deficit, the Special Region of Yogyakarta will be in a position of dependence on other regions related to rice supply.

The dependence on rice had an impact on rice price fluctuations in the local market, because rice supply was very dependent on the availability of rice in other regions. Meanwhile, if proper supervision was not performed, then local farmers can be harmed if it turned out that rice from other regions was cheaper than the selling price of local farmers.

Table 5. Rice Field Area in the Special Region of Yogyakarta Based on the Actual

Value and Forecasting Result of Linear and Exponential Trend, 2017 - 2021

\begin{tabular}{cccccccc}
\hline Year & $\begin{array}{c}\text { Actual } \\
\text { data }\end{array}$ & $\begin{array}{c}\text { Linear } \\
\text { Trend }\end{array}$ & error & error (\%) & $\begin{array}{c}\text { Exponential } \\
\text { Trend }\end{array}$ & error & $\begin{array}{c}\text { error } \\
\text { (\%) }\end{array}$ \\
\hline 2017 & 52.474 & 52.264 & -210 & $-0,4003 \%$ & 52.499 & 25 & 0,0483 \\
2018 & na & 52.018 & na & na & 52.277 & na & na \\
2019 & na & 51.773 & na & na & 52.055 & na & na \\
2020 & na & 51.528 & na & na & 51.834 & na & na \\
2021 & na & 51.282 & na & na & 51.614 & na & na \\
\hline
\end{tabular}

Information: na $=$ data not available

\section{CONCLUSION}

The development of rice field area in Special Region of Yogyakarta tended to decrease from year to year. Through the three measurement parameters of the model, it was known that the exponential trend was the most appropriate model to predict the rice fields area in the Special Region of Yogyakarta compared to the linear trend model and the quadratic trend model. From 2017 to 2021, it was estimated that the conversion of rice fields to non-agricultural land will continue at a rate of 221 hectares or 0.41 percent per year. 


\section{RECOMMENDATION}

The availability of data over a long period of time was a weakness of this research. Therefore, in the next research, forecasting of rice fields can be done by using data over a longer period of time. Other study to support this research was the factors that affected land conversion. Thus, an illustration of the causes of land conversion will be more comprehensive. Responding to the development of rice fields area which tended to decrease from year to year, the government as a policy maker need to issue budget policies that favor to the farmers including upstream, cultivation, and downstream. This was in accordance with the strategic role of farmers as actors that providing the basic needs of the community.

\section{REFERENCES}

Abdillah, A. H., \& Zaini, A. (2018). Analisis Kebutuhan dan Kemampuan Penyediaan Konsumsi Padi di Kabupaten Tana Tidung. Pertanian Terpadu, VI(1), 39-45.

Adimihardja, A. (2006). Strategi Mempertahankan Multifungsi Pertanian di Indonesia. Jurnal Penelitian Dan Pengembangan Pertanian, 25(3).

Alfarisi, S., \& Sunarmintyastuti, L. (2018). Pengembangan Aplikasi untuk Meramalkan Penjualan Bordir Tasikmalaya Menggunakan Metode Penghalusan Eksponensial. Jurnal Penelitian Pos \& Informatika, 8(1), 21-36.

Ashari, N. (2003). Tinjauan tentang Alih Fungsi Lahan Sawah ke Non Sawah dan Dampaknya di Pulau Jawa. Forum Penelitian Agro Ekonomi, 21(2), 83-98. https://doi.org/10.21082/fae.v21n2.2003.83-98

BPS. (2019). Provinsi Daerah Istimewa Yogyakarta Dalam Angka 2019.

BPS. (2020a). Lahan yang dikuasai (m2) Lahan bukan sawah. Https://Sirusa.Bps.Go.Id/Sirusa/Index.Php/Variabel/2609.

BPS. (2020b). Luas Lahan Sawah menurut Provinsi sejak tahun 2003 hingga 2015. https://www.bps.go.id/linkTableDinamis/view/id/895

Catur, T., Purwanto, J., Uchyani, R., \& Ani, S. W. (2010). Dampak Alih Fungsi Lahan Pertanian ke Sektor Pertanian terhadap Ketersediaan Beras di Kabupaten Klaten Provinsi Jawa Tengah. Jurnal Caraka Tani, 15(1), 38-42.

Dewi, N. K., \& Rudiarto, I. (2013). Identifikasi Alih Fungsi Lahan Pertanian dan Kondisi Sosial Ekonomi Masyarakat Daerah Pinggiran di Kecamatan Gunungpati Kota Semarang. Jurnal Wilayah Dan Lingkungan, 1(2), 175-188. https://doi.org/10.14710/jwl.1.2.175-188

Dwiyansany, S., \& Wardhani, L. T. A. L. (2019). Sistem Pertanahan Keraton Yogyakarta Sebagai Daerah Otonomi Khusus. Jurnal Pembangunan Hukum Indonesia, 1(2), 226-236

Dinas Pariwisata DIY. (2019). Statistik Kepariwisataan 2018. 
Faisaluddin, A., Fazlina, Y. D., \& Sugianto. (2019). Prediksi Ketersediaan Lahan Sawah Menggunakan Metode Forecasting Di Kecamatan Darussalam. Jurnal Ilmiah Mahasiswa Pertanian, 4(1), 690-698.

Hidayat, S. I. (2008). Analisis Konversi Lahan Sawah di Propinsi Jawa Timur. J-SEP, 2(3), 48-58.

Hidayatullah, A. I., \& Perihatini, D. I. (2016). Hierarchical Cluster Analysis Terhadap Pelanggan Pasar Beringharjo Yogyakarta. Konferensi Nasional Penelitian Matematika Dan Pembelajarannya (KNPMP I), 981-989.

Irawan, B., \& Ariningsih, E. (2010). Dinamika Kebijakan dan Ketersediaan Lahan Pertanian. Panel Petani Nasional Mobilisasi Sumberdaya Dan Penguatan Kelembagaan Pertanian, 9-25.

Irawan, B., \& Friyatno, S. (2002). Dampak Konversi Lahan Sawah di Jawa Terhadap Produksi Beras dan Kebijakan Pengendaliannya. SOCA Jurnal Sosial-Ekonomi Pertanian Dan Agribisnis, 2(2), 1-33.

Isa, I. (2006). Strategi Pengendalian Alih Fungsi Lahan Pertanian. Seminar Multifungsi Dan Revitalisasi Pertanian. Balai Penelitian Tanah, Bogor., 17.

Jati, W. R. (2014). Politik Agraria di Yogyakarta: Identitas Partrimonial \& Dualisme Hukum Agraria. Jurnal Legislasi Indonesia, 11(1), 25-37. https://doi.org/10.1017/CBO9781107415324.004

Janti, gesthi ika, Martono, E., \& Subejo. (2016). Perlindungan Lahan Pertanian Pangan Berkelanjutan (Bantul, DI Yogyakarta). Jurnal Ketahanan Nasional, 22(1), 1-21.

Maulana, R., \& Ma'rif, S. (2019). Arahan Lahan Insentif Pertanian Pangan Berkelanutan Kabupaten Boyolali. Teknik PWK (Perencanaan Wilayah Kota), 8(1), 12-19.

Nurelawati, A., Sutrisno, J., \& Fajarningsih, R. U. (2018). Tren Alih Fungsi Lahan Pertanian Di Kabupaten Klaten. Peran Keanekaragaman Hayati Untuk Mendukung Indonesia Sebagai Lumbung Pangan Dunia, 2(1), B.41-B.50.

Prasada, I. M. Y., \& Rosa, T. A. (2018). Dampak Alih Fungsi Lahan Sawah Terhadap Ketahanan Pangan Di Daerah Istimewa Yogyakarta. Jurnal Sosial Ekonomi Pertanian, 14(3), 210-224. https://doi.org/10.20956/jsep.v14i3.4805

Putri, Z. R. (2015). Analisis Penyebab Alih Fungsi Lahan Pertanian Ke Lahan Non Pertanian Kabupaten/Kota di Provinsi Jawa Tengah 2003-2013. Eko-Regional, 1O(1), 17-22.

Rahmawati. (2015). Model Trend untuk Peramalan Jumlah Penduduk. JTRISTE, 2(2), 46-52. https://doi.org/10.1017/CBO9781107415324.004 
Rakhman, A., \& Puspitasari, N. B. (2017). Usulan Perbaikan Perencanaan Produksi pada Produk Engine Tipe CJ untuk Mobil Pick Up di PT. XYZ dengan Metode TIME - Series. Industrial Enginering Online Journal, 6(1).

Ritung, S. (2010). Lahan Sawah dan Kecukupan Produksi Bahan Pangan. Jurnal Sumberdaya Lahan, 4(1), 27-38.

Robial, S. M. (2018). Perbandingan Model Statistik pada Analisis Metode Peramalan Time Series (Studi Kasus: PT. Telekomunikasi Indonesia, Tbk Kandatel Sukabumi). Jurnal Ilmiah SANTIKA, 8(2), 1-17.

Rori, H. (2013). Analisis Penerapan Tax Planning Atas Pajak Penghasilan Badan. Jurnal Riset Ekonomi, Manajemen, Bisnis Dan Akuntansi, 1(3), 410-418.

Sakinah, F., Sukiyono, K., \& Reswita. (2018). Pendugaan Model Peramalan Harga dan Integrasi Pasar Spasial Kacang Tanah. JISEB, 21(2), 76-87. https://doi.org/10.22437/jiseb.v21i2.5541

Sungkawa, I., \& Megasari, R. T. (2011). Penerapan Ukuran Ketepatan Nilai Ramalan Data Deret Waktu dalam Seleksi Model Peramalan Volume Penjualan PT Satriamandiri Citramulia. ComTech, 2(2), 636-645.

Sukerti, N. K. (2015). Peramalan Deret Waktu Menggunakan S-Curve dan Quadratic Trend Model. Konferensi Nasional Sistem \& Informatika, 592-597.

Sukiyono, K., \& Rosdiana, R. (2018). Pendugaan Model Peramalan Harga Beras Pada Tingkat Grosir. Jurnal AGRISEP, 17(1), 23-30. https://doi.org/10.31186/jagrisep.17.1.23-30

Telaumbanua, P., \& Pitoyo, A. J. (2017). Migrasi Risen di Provinsi Daerah Istimewa Yogyakarta Hasil Sensus Penduduk Tahun 1980-2010. Jurnal Bumi Indonesia2, 6(1). https://doi.org/10.1017/CBO9781107415324.004

Wibowo, C. S. (2015). Dampak Pengalihan Fungsi Lahan Sawah Pada Produksi Padi Sampai Tahun 2018 Dan Implikasinya Terhadap Ketahanan Pangan Wilayah (Studi di Kecamatan Jaten Kabupaten Karanganyar Propinsi Jawa Tengah). Jurnal Ketahanan Nasional, 21(2), 107-117. https://doi.org/10.22146/jkn.10154

Widjanarko, B. S., Pakpahan, M., Rahardjono, B., \& Putu, S. (2001). Aspek Pertanahan Dalam Pengendalian Alih Fungsi Lahan Pertanian (Sawah). Seminar Nasional Multifungsi Lahan Sawah, 19-28. http:/ / balittanah.litbang.pertanian.go.id/ind/dokumentasi/prosiding/mflp20 01/bambangwidjanarko.pdf

Yoga Prasada, I., \& Masyhuri, M. (2020). Availability Of Agricultural Land And Fulfillment Of Population Food Needs In Urban Region (Case Study of Pekalongan City, Tengah Jawa). Agricultural Social Economic Journal, 20(1), 3138. https://doi.org/10.21776/ub.agrise.2020.020.1.5 
Zulfikar, M., Barus, B., \& Sutandi, A. (2013). Pemetaan Lahan Sawah dan Potensinya untuk Perlindungan Sawah Pertanian Pangan Berkelanjutan di Kabupaten Pasaman Barat, Sumatera Barat. Jurnal Tanah Lingkungan, 15(1), 20-28. 